\title{
Estrogen receptor (ER) expression and function in the pregnant human myometrium: estradiol via ER $\alpha$ activates ERK1/2 signaling in term myometrium
}

\author{
Toni Welsh ${ }^{1,2}$, Matrika Johnson ${ }^{1}$, Lijuan $\mathrm{Yi}^{1}$, Huiqing Tan ${ }^{1}$, Roksana Rahman ${ }^{1}$, Amy Merlino ${ }^{1}$, \\ Tamas Zakar ${ }^{2,3}$ and Sam Mesiano \\ ${ }^{1}$ Department of Reproductive Biology, Case Western Reserve University, 11100 Euclid Avenue, Cleveland, Ohio 44106, USA \\ ${ }^{2}$ Mothers and Babies Research Centre, University of Newcastle, Newcastle, New South Wales 2308, Australia \\ ${ }^{3}$ Department of Obstetrics and Gynaecology, John Hunter Hospital, Newcastle, New South Wales 2305, Australia \\ (Correspondence should be addressed to S Mesiano; Email: sam.mesiano@case.edu)
}

\begin{abstract}
Estrogens are thought to promote labor by increasing the expression of pro-contraction genes in myometrial cells. The specific estrogen receptors ((ERs: ER $\alpha$ and ER $\beta$ (also known as ESR 1 and ESR2)) and $G$ protein-coupled receptor 30 (GPR30; also known as G protein-coupled estrogen receptor 1)) and signaling pathways that mediate these actions are not clearly understood. In this study, we identified the ERs expressed in the pregnant human myometrium and determined a key extranuclear signaling pathway through which estradiol $\left(E_{2}\right)$ modulates expression of the gene encoding the oxytocin receptor (OXTR), a major pro-contraction protein. Using quantitative RT-PCR, we found that ER $\alpha$ and GPR30 mRNAs were expressed in the human pregnant myometrium while $E R \beta$ mRNA was virtually undetectable. While mRNA encoding ER $\alpha$ was the predominant ER transcript in the pregnant myometrium, ER $\alpha$ protein was largely undetectable in myometrial tissue by immunoblotting. Pharmacological
\end{abstract}

inhibition of $26 \mathrm{~S}$ proteasome activity increased $\mathrm{ER} \alpha$ protein abundance to detectable levels in term myometrial explants, however, indicating rapid turnover of $\mathrm{ER} \alpha$ protein by proteasomal processing in the pregnant myometrium. $\mathrm{E}_{2}$ stimulated rapid extranuclear signaling in myometrial explants, as evidenced by increased extracellularly regulated kinase (ERK1/2) phosphorylation within $10 \mathrm{~min}$. This effect was inhibited by pre-treatment with an ER antagonist, ICI 182780 , indicating the involvement of ER $\alpha$. Inhibition of ERK signaling abrogated the ability of $\mathrm{E}_{2}$ to stimulate OXTR gene expression in myometrial explants. We conclude that estrogenic actions in the human myometrium during pregnancy, including the stimulation of contraction-associated gene expression, can be mediated by extranuclear signaling through ER $\alpha$ via activation of the ERK/mitogen-activated protein kinase pathway.

Journal of Endocrinology (2012) 212, 227-238

\section{Introduction}

Estrogens (mainly estradiol $\left(\mathrm{E}_{2}\right)$ ) promote labor by stimulating biochemical and physical changes in myometrial cells that augment uterine contractility and excitability (for review, see Pepe \& Albrecht (1995)). Studies on various species have shown that $\mathrm{E}_{2}$ increases the expression of genes in myometrial cells encoding gap junction proteins that form low-resistance connections between myometrial cells to promote synchronized contractions (Lye et al. 1993, Petrocelli \& Lye 1993, Kilarski et al. 1996, 2000), receptors for uterotonic hormones such as oxytocin and prostaglandin $\mathrm{F}_{2 \alpha}\left(\mathrm{PGF}_{2 \alpha}\right.$; Pinto et al. 1966, 1967, Nissenson et al. 1978), and enzymes such as PG-endoperoxide synthase-2 (PTGS2), the main inducible rate-limiting enzyme for PG synthesis (Mesiano et al. 2002). Although it is generally accepted that these actions are mediated by estrogen receptors (ERs), the specific ERs and associated signaling pathways are not well characterized in the pregnant human myometrium. Human ERs exist in three principal forms: two classical nuclear ER subtypes, ER $\alpha$ (also called ESR1) and ER $\beta$ (ESR2; Warner et al. 1999, Dechering et al. 2000), and a seven-transmembrane $G$ protein-coupled receptor known as GPR30 (alternatively known as G proteincoupled estrogen receptor 1 (GPER); Revankar et al. 2005, Thomas et al. 2005). The purpose of this study was to determine whether these ERs are expressed in the pregnant human myometrium and to investigate the signaling pathways through which they mediate estrogenic actions.

In most species, the pro-labor influence of estrogens is achieved by a marked increase in circulating estrogen concentrations prior to the onset of labor. In human pregnancy, however, the myometrium is exposed to high levels of estrogens in the form of $\mathrm{E}_{2}$, estrone, and estriol for most of pregnancy and systemic estrogen levels do not change 
significantly prior to labor onset (De Hertogh et al. 1975, Smith et al. 2009). It appears, therefore, that the human myometrium is refractory to the pro-contractile actions of estrogens for most of pregnancy and that the parturition process involves increased myometrial responsiveness to estrogens. We have previously found that myometrial $E R \alpha$ mRNA levels rise at parturition and that the levels are strongly correlated with the abundance of $\mathrm{mRNAs}$ encoding PTGS2 and the oxytocin receptor (OXTR; Mesiano et al. 2002). However, attempts to measure ER $\alpha$ protein in pregnant human myometrium by immunohistochemistry (Geimonen et al. 1998, Winkler et al. 2002, Laudanski et al. 2004) or immunoblotting (Geimonen et al. 1998) have been largely unsuccessful, and it is well documented that ER $\alpha$ expression is substantially reduced during pregnancy compared with the non-pregnant state (Geimonen et al. 1998, Benassayag et al. 1999). Wu et al. (2000) reported that $\mathrm{ER} \beta$ but not $\mathrm{ER} \alpha$ was detectable by immunoblotting in term human myometrium and suggested that $\operatorname{ER} \beta$ is the principal mediator of estrogenic actions in the pregnant human uterus. However, we found that ER $\beta$ mRNA was barely detectable by the very sensitive real-time RT-PCR technique in term myometrium (Mesiano et al. 2002). Thus, there is a lack of consensus regarding the expression of $\operatorname{ER} \alpha$ and $\operatorname{ER} \beta$ in the pregnant human myometrium and their role in mediating estrogen actions, which is further complicated by the possibility that GPR 30 is also involved in estrogen signaling in myometrial cells (Maiti et al. 2011).

Estrogens typically affect target cell function via the genomic mode of steroid hormone action, whereby ER $\alpha$ and $\operatorname{ER} \beta$ function as ligand-activated transcription factors to modulate the expression of specific genes. However, many pro-contraction genes that are regulated by $\mathrm{E}_{2}$, including OXTR and connexin-43 (GJA1), lack complete canonical estrogen response elements (EREs) in their promoter regions (Geimonen et al. 1996, Gimpl \& Fahrenholz 2001). This suggests that $\mathrm{E}_{2}$ modulates the expression of some genes via alternative mechanisms. One possibility is that $\mathrm{E}_{2}$ regulates the expression of ERE-containing genes via the classical genomic mode of action and that the products of those genes then regulate the expression of secondary or tertiary gene sets. An alternative possibility is that estrogens activate extranuclear/non-genomic pathways that lead to downstream changes in gene expression (reviewed in Vasudevan \& Pfaff (2008), Fox et al. (2009), and Prossnitz \& Maggiolini (2009)). Unlike the genomic mode of action, the extranuclear mode affects cell function directly by modulating cytoplasmic signaling cascades that impact on the activity of multiple cellular processes and transcription factors. Extranuclear pathways activated by $\mathrm{E}_{2}$ include the extracellularly regulated kinase (ERK)/mitogen-activated protein kinase (MAPK) and phosphatidylinositol 3-kinase/protein kinase B (PKB/AKT) pathways, as well as $\mathrm{Ca}^{2+}$ influx and $\mathrm{G}$ protein signaling (Vasudevan \& Pfaff 2008, Fox et al. 2009, Prossnitz \& Maggiolini 2009). ER $\alpha, \operatorname{ER} \beta$, and GPR30 have each been found to induce extranuclear signaling, although the involvement of the different receptors appears to be tissueand cell-type specific (Vasudevan \& Pfaff 2008, Fox et al. 2009, Prossnitz \& Maggiolini 2009). Rapid activation of the ERK/MAPK signaling pathway by $\mathrm{E}_{2}$ has been extensively studied in breast cancer cells where this cascade is thought to mediate the proliferative response to estrogens (Migliaccio et al. 1996, Razandi et al. 2003, Song et al. 2002, 2004). Upon ligand binding, $\mathrm{ER} \alpha$ and $\mathrm{ER} \beta$ can interact with numerous scaffolding proteins and signaling molecules in the cytoplasm, including SRC (Migliaccio et al. 1996, Barletta et al. 2004), MNAR (Barletta et al. 2004), SHC (Song et al. 2002, 2004), and $G$ proteins (Kumar et al. 2007), and in concert with these proteins stimulate downstream activation of ERK1/2 (also known as p44/42 MAPK). GPR30 activates rapid nongenomic signaling via its coupled $\mathrm{G}$ proteins, which activate SRC and the downstream ERK pathway, often by way of extracellular release of heparin-bound epidermal growth factor (HB-EGF) and transactivation of the EGF receptor (reviewed in Maggiolini \& Picard (2010)). Madak-Erdogan et al. (2008) have found that the extranuclear actions of $\mathrm{E}_{2}$ mediated by $\mathrm{ER} \alpha$ controlled $\sim 25 \%$ of all $\mathrm{E}_{2}$-responsive genes in MCF7 breast cancer cells, highlighting the importance of extranuclear $\mathrm{ER} \alpha$ signaling in mediating ligand-activated gene expression.

Extranuclear signaling by estrogens is largely unexplored in pregnant human myometrium. In pregnant rats, the abundance of activated ERK in myometrial cells increases with gestation (Oldenhof et al. 2002, Serrano-Sanchez et al. 2008) and labor onset (Li et al. 2003). In animals induced to deliver preterm (PT) by administration of the progesterone receptor antagonist RU486, concurrent inhibition of ERK signaling delayed preterm labor and decreased myometrial contractility (Li et al. 2004). These data emphasize the potential importance of this pathway in the regulation of myometrial smooth muscle contractility. In this study, we characterized the ERs expressed in the pregnant human myometrium and determined whether they activate the cytoplasmic ERK signaling cascade in response to $E_{2}$ in explant cultures of term human myometrium.

\section{Materials and Methods}

\section{Myometrial tissue collection}

Lower uterine segment myometrium was obtained following collection of written informed consent from women undergoing cesarean section at MacDonald Women's Hospital, University Hospitals Case Medical Center, Cleveland, $\mathrm{OH}$ (IRB approval \#11-04-06), and MetroHealth Medical Center, Cleveland, OH (IRB approval \#05-00287). A biopsy of myometrium $\left(\sim 0.5 \mathrm{~cm}^{3}\right)$ was excised from the upper margin of the lower segment incision after delivery of the placenta. Tissue was collected from women delivering at PT and not in labor (NIL) (PT-NIL; $n=6$; range $27 \mathrm{wOd}-34$ $\mathrm{w} 2 \mathrm{~d}$ ), at PT and in labor (IL) (PT-IL; $n=6$; range $24 \mathrm{w} 1 \mathrm{~d}-36$ 
w6d), at term and NIL (T-NIL; $n=19$; range $37 \mathrm{w} 3 \mathrm{~d}-41$ w6d), and at term and IL (T-IL; $n=11$; range $38 \mathrm{w} 1 \mathrm{~d}-40$ w4d). Cesarean sections were performed in non-laboring women for complications such as pre-eclampsia, breech presentation, or previous cesarean section, while indications for cesarean section during labor included fetal distress, maternal complications, or failure to progress. Samples from pregnancies with induced labor or clinical signs of chorioamnionitis were excluded. Tissues were rinsed in ice-cold PBS and portions of each myometrial specimen were immediately snap-frozen in liquid nitrogen or placed in fixative (10\% neutral-buffered formalin). Tissue samples used for explant studies were transported to the laboratory in PBS on ice for further processing. Non-pregnant myometrium was collected from women undergoing surgery for benign gynecological conditions at MacDonald Women's Hospital (IRB approval \#06-07-29) and snap-frozen in liquid nitrogen.

\section{Myometrial explant culture}

Myometrial tissue samples collected from women at term and NIL were dissected into explants of $2-3 \mathrm{~mm}^{3}$ and placed onto $0 \cdot 2 \mu \mathrm{m}$ polycarbonate filters (GE Water \& Process Technologies, Trevose, PA, USA) floating on $2 \mathrm{ml}$ of phenol red-free, serum-free DMEM (Sigma) containing $2 \mathrm{~mm}$ GlutaMAX (Invitrogen), $100 \mathrm{U} / \mathrm{ml}$ penicillin, and $100 \mu \mathrm{g} / \mathrm{ml}$ streptomycin in 6-well plates and cultured overnight $\left(16-18 \mathrm{~h}\right.$ ) at $37^{\circ} \mathrm{C}$ in $5 \% \mathrm{CO}_{2}, 95 \%$ air (six to seven explants per well). Media were refreshed and the explants were incubated with media alone or U0126 $(10 \mu \mathrm{M})$ (Cell Signaling, Beverly, MA, USA), ICI 182780 (1 $\mu \mathrm{M}$; Sigma), or vehicle for $30 \mathrm{~min}$. $\mathrm{E}_{2}, 1$ or $10 \mathrm{~nm}$ (Sigma), phorbol myristate acetate (PMA; $100 \mathrm{~nm}$ ), or vehicle was then added for various times, and the explants were snap-frozen in liquid nitrogen. The viability of myometrial explants in this culture system was confirmed by histological analysis showing few necrotic cells and maintenance of smooth muscle-specific marker expression and RNA integrity (data not shown). For $26 \mathrm{~S}$ proteasome inhibition experiments, explants were placed into culture and stimulated without delay with vehicle or MG132 (10 $\mu \mathrm{M}$; Sigma) for $24 \mathrm{~h}$. Nuclear and cytoplasmic protein extracts were then immediately prepared using the Nuclear Extract Kit (Active Motif, Carlsbad, CA, USA) according to the manufacturer's instructions.

\section{Cell culture and transfection}

The hTERT-HM cell line, a telomerase-immortalized myometrial smooth muscle cell line derived from the fundus of a non-pregnant, pre-menopausal woman (Condon et al. 2002), was provided by Prof. William Rainey, Medical College of Georgia. Cells were cultured in complete media: phenol redfree DMEM containing 10\% charcoal-stripped FCS, $2 \mathrm{~mm}$ GlutaMAX, $100 \mathrm{U} / \mathrm{ml}$ penicillin, and $100 \mu \mathrm{g} / \mathrm{ml}$ streptomycin at $37^{\circ} \mathrm{C}$ in $5 \% \mathrm{CO}_{2}, 95 \%$ air. Cells at $90-95 \%$ confluency were collected by trypsinization, centrifuged, and resuspended in Amaxa Nucleofector Mammalian Smooth Muscle Cell Solution (Lonza, Walkersville, MD, USA) at a concentration of $2 \times 10^{6}$ cells $/ 100 \mu$ l solution. siRNA targeted against exon 8 of $E R \alpha$ (Silencer Select Pre-Designed siRNA ID s4824; Ambion) or Silencer Select Negative Control \#1 siRNA (Ambion) was added to the transfection solution at 375 or $750 \mathrm{~nm}$ each. The transfection solution $(100 \mu \mathrm{l})$ was transferred to an electroporation cuvette and nucleofection was achieved using the Amaxa Nucleofector Device with program A33. The transfection solution was then diluted in $8 \mathrm{ml}$ complete media and plated at $0.5 \times 10^{6}$ cells $/ 35 \mathrm{~mm}$ dish. A subset of cells were co-transfected with an expression plasmid encoding full-length ER $\alpha\left(1 \mu \mathrm{g}\right.$ plasmid DNA $/ 0.5 \times 10^{6}$ cells $)$ provided by Dr Peter Kushner, University of California at San Francisco. The cells were cultured for $48 \mathrm{~h}$ before lysis at $4{ }^{\circ} \mathrm{C}$ using CelLytic MT Lysis Buffer (Sigma) supplemented with protease and phosphatase inhibitors (Sigma). T47D and MCF7 human breast carcinoma cells were obtained from the American Type Culture Collection (Manassas, VA, USA) and were used as positive controls for ER expression.

\section{Immunoblotting}

Whole tissue protein extracts were prepared from myometrium by homogenization in CelLytic MT Lysis Buffer supplemented with protease and phosphatase inhibitors on ice. Tissue homogenates were centrifuged at $10000 \mathrm{~g}$ at $4{ }^{\circ} \mathrm{C}$ for $10 \mathrm{~min}$ and the supernatants were collected and assayed for total protein content using the Quick Start Bradford Protein Assay (Bio-Rad). Cell lysates were incubated with reducing sample buffer and subjected to SDS-PAGE (20-200 $\mu \mathrm{g}$ protein/lane) using Pierce 10\% Precise Protein Gels (Thermo Fisher Scientific, Rockford, IL, USA). Proteins were transferred to polyvinyl difluoride (PVDF) membranes and non-specific binding was blocked using either 5\% BSA (for phospho-antibodies) or 5\% skimmed milk (for non-phosphoantibodies) in $20 \mathrm{~mm}$ Tris, $150 \mathrm{~mm} \mathrm{NaCl}$, pH 7.5, containing $0 \cdot 1 \%$ Tween-20 (TTBS) for $1 \mathrm{~h}$ at room temperature. Membranes were incubated with primary antibodies (Table 1) diluted in blocking buffer overnight at $4{ }^{\circ} \mathrm{C}$, then washed, and incubated with secondary antibody (anti-mouse or anti-rabbit IgG-HRP; 1:3000; Cell Signaling) at room temperature for $1 \mathrm{~h}$. The membranes were washed, incubated with Amersham ECL chemiluminescent reagent (GE Healthcare, Piscataway, NJ, USA), and exposed to autoradiography film (Denville Scientific, South Plainfield, NJ, USA). The resultant bands were quantified using digital densitometry (Fujifilm MultiGauge v 3.0 Software; Fuji Photo Film Co., Tokyo, Japan). Where required, the PVDF membranes were dried, re-wet in methanol, and re-probed with antibodies directed against loading control proteins or nuclear markers. The effective stripping of each primary antibody between blots was confirmed by a lack of signal upon incubation with secondary antibody alone with chemiluminescent detection. 
Table 1 Primary antibodies used for western blotting

\begin{tabular}{|c|c|c|c|c|}
\hline Antibody target & Clone/designation & Species & Supplier & Dilution \\
\hline $\mathrm{ER} \alpha$ & F10 & Mouse & Santa Cruz (Santa Cruz, CA, USA) & $1: 1000$ \\
\hline $\mathrm{ER} \alpha$ & HC20 & Rabbit & Santa Cruz & $1: 1000$ \\
\hline $\mathrm{ER} \alpha$ & C-542 & Mouse & Calbiochem (Rockland, MA, USA) & $1: 1000$ \\
\hline GPR30 & LS-A4272 & Rabbit & Lifespan Biosciences (Seattle, WA, USA) & $1: 500$ \\
\hline GAPDH & $6 C 5$ & Mouse & Santa Cruz & $1: 50000$ \\
\hline 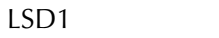 & C69G12 & Rabbit & Cell Signaling & $1: 1000$ \\
\hline Phospho-ERK1/2 & 9101 & Rabbit & Cell Signaling & $1: 1000$ \\
\hline Total ERK1/2 & 9102 & Rabbit & Cell Signaling & $1: 2000$ \\
\hline
\end{tabular}

\section{$R N A$ extraction and quantitative RT-PCR}

RNA was extracted from myometrial tissues and T47D cells using Trizol reagent (Invitrogen) according to the manufacturer's instructions. Total RNA extracts were treated with DNase (Ambion) to remove residual DNA and quantified by u.v. spectrometry. RNA integrity was determined by agarose gel electrophoresis. Total RNA $(1 \mu \mathrm{g})$ was reverse transcribed to cDNA using the Superscript II or III First-Strand Synthesis Systems for RT-PCR (Invitrogen) with random hexamer primers. Real-time PCR was performed using an ABI PRISM 7500 Sequence Detector with SYBR Green fluorescence detection (Applied Biosystems, Carlsbad, CA, USA). PCR primers (Table 2) were designed using Primer Express Software (Applied Biosystems). The abundance of specific mRNAs in myometrial tissues and explants were determined relative to the abundance of h-caldesmon $(h \mathrm{CaD})$ mRNA using the $\Delta C_{\mathrm{t}}$ calculation (Livak \& Schmittgen 2001). We had determined in previous experiments that the levels of $h \mathrm{CaD}$ mRNA (which is expressed specifically in smooth muscle) do not change significantly in the myometrium with advancing gestational age (GA) or labor onset (linear regression performed on logarithmically transformed data showed no relationship between $h \mathrm{CaD}$ mRNA and GA $\left(r^{2}=0.0286, P=0.464 ; n=21\right)$ or labor status $\left(r^{2}=0.0009\right.$, $P=0 \cdot 897 ; n=21)$ ). PCR efficiency for each amplicon was calculated using LinRegPCR version 11.1 Software (Ruijter et al. 2009). T47D cell line cDNA served as a positive control for $E R \alpha, E R \beta$, and GPR30 expression.

\section{Data analysis}

The distribution of data was assessed using the Skewness and Kurtosis test for normality. Comparisons between two groups of normally distributed data were performed by Student's $t$ test (paired or unpaired as appropriate). Phospho-ERK expression in myometrial explants was assessed by repeated measures ANOVA and differences between treatments were analyzed by paired $t$-test with Bonferroni's correction for multiple comparisons. Linear regression was performed to examine the relationships between a number of variables $(E R \alpha$ mRNA, ER $\beta$ mRNA (logarithmically transformed data), GPR30 mRNA (logarithmically transformed data), GPR 30 protein, pERK1 expression (square-root transformed data), pERK2 or total ERK expression, or the ratio of pERK1 and pERK2 to total ERK (square-root transformed data)) and GA or labor. Spearman's rank correlation was used to test the relationship between GPR30 mRNA and protein data. Explant OXTR mRNA data were examined using repeated measures ANOVA with Dunnett's post-hoc test. The data were analyzed using GraphPad Prism version 5.03 (GraphPad Software, Inc., San Diego, CA, USA) or Stata version 11 (StataCorp LP, College Station, TX, USA) and $P<0 \cdot 05$ was considered significant for all analyses.

\section{Results}

\section{ER expression in the pregnant human myometrium}

$E R \alpha$ and GPR30 mRNAs were readily detectable in pregnant human myometrium (Fig. 1). However, $E R \beta$ mRNA was detected at extremely low levels by quantitative RT-PCR (qRT-PCR). T47D cell cDNA served as a positive control for $E R \beta$ expression and confirmed the functionality of our PCR primers. There was no relationship between $E R \beta$ mRNA abundance and GA or labor status (linear regression performed on log-transformed data; $E R \beta$ vs GA, $r^{2}=0 \cdot 018$,

Table 2 Real-time PCR primer sequences

\begin{tabular}{|c|c|c|c|}
\hline $\begin{array}{l}\text { Target } \\
\text { mRNA }\end{array}$ & $\begin{array}{l}\text { Amplicon } \\
\text { size (bp) }\end{array}$ & $\begin{array}{l}\text { GenBank } \\
\text { accession no. }\end{array}$ & $\begin{array}{l}\text { Forward } \\
\text { primer }\left(5^{\prime}-3^{\prime}\right)\end{array}$ \\
\hline$E R \alpha$ & 66 & NM_000125.3 & TGAAAGGTGGGATACGAAAAGAC \\
\hline$E R \beta$ & 101 & NM_001437.2 & CACGTCAGGCATGCGAGTAA \\
\hline GPR30 & 78 & NM_001505.2 & TGCACCTTCATGTCGCTCTT \\
\hline OXTR & 73 & NM_000916.3 & CTGGACGCCTTTCTTCTTCGT \\
\hline$h C a D$ & 79 & NM_033138.2 & CAGAGAGGGCAAGGTTGGAA \\
\hline
\end{tabular}

\begin{tabular}{l}
$\begin{array}{l}\text { Reverse } \\
\text { primer }\left(5^{\prime}-3^{\prime}\right)\end{array}$ \\
\hline CATCTCTCTGGCGCTTGTGTT \\
GCATTCAGCATCTCCAGCAG \\
GCGGTCGAAGCTCATCCA \\
GAAGGCCGAGGCTTCCTT \\
GCTCGTTCATCTGCTATCTTTTTG
\end{tabular}


Myometrial estrogen receptor mRNA

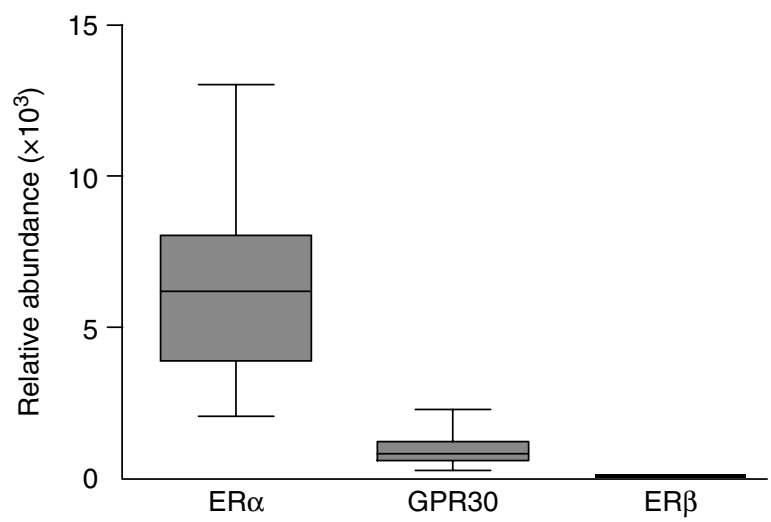

Figure 1 ER mRNA relative abundance in pregnant human myometrium. The receptor groups include myometrial samples from a range of gestational ages, $n=21$ each ( 14 non-laboring and seven laboring tissue samples). The box and whiskers plots demonstrate the median values, with the boxes extending to the 25th and 75th percentiles and the whiskers extending to the minimum and maximum values.

$P=0 \cdot 563 ; E R \beta$ vs labor, $\left.r^{2}=0 \cdot 0172, P=0 \cdot 571 ; n=21\right)$. Owing to the very low levels of $E R \beta$ gene expression, it is unlikely that this receptor plays an important role in mediating estrogen signaling in the pregnant human myometrium. ER $\alpha$ mRNA levels did not change significantly with GA (linear regression; $r^{2}=0 \cdot 0064, P=0 \cdot 730$; $n=21$ ) but were significantly higher in myometrial samples from laboring compared with non-laboring women $\left(r^{2}=0 \cdot 1949, P=0 \cdot 045 ; n=21\right)$. The amplification efficiency for all amplicons, as assessed by the LinRegPCR Software, was close to the theoretical efficiency value of $2(E R \alpha$, $2 \cdot 009 \pm 0.005$ (mean \pm s.E.M.); ER $\beta, 1.955 \pm 0.022$; GPR30, $1 \cdot 950 \pm 0 \cdot 007 ; \mathrm{hCaD} 2 \cdot 002 \pm 0 \cdot 006 ;$ assessed in $17-22$ individual PCR reactions each). These comparable amplification efficiencies allow us to assess the relative expression of different ER mRNA species with reasonable confidence, and together with the pronounced differences in ER mRNA levels shown in Fig. 1, lead us to conclude that ER $\alpha$ is the predominantly expressed ER in the pregnant human myometrium at the mRNA level.

ER $\alpha$ protein expression was examined in non-pregnant myometrium and in pregnant myometrium at various gestational stages by immunoblotting (Fig. 2). The representative results shown in Fig. $2 \mathrm{~A}$ and $\mathrm{B}$ were from tissues that were snap-frozen at the time of collection, not from cultured explants. We found robust expression of full-length ER $\alpha$ protein in the non-pregnant myometrium and in MCF7 breast cancer cells. ER $\alpha$ protein levels were substantially lower in pregnant myometrial tissues than in non-pregnant myometrium, which was expected as similar results have been reported previously (Geimonen et al. 1998). ER $\alpha$ protein was detected in one of four PT-NIL myometrial samples, two of six PT-IL samples, one of ten T-NIL samples, and two of ten
T-IL samples. Three different ER $\alpha$ antibodies were screened for their ability to detect $E R \alpha$ protein in the pregnant human myometrium; representative results are shown for a monoclonal $(\mathrm{ER} \propto$ F10; Fig. 2A) and a polyclonal (ER $\alpha$ HC20; Fig. 2B) antibody. Both antibodies detected a $66000 \mathrm{M}_{\mathrm{r}}$ immunoreactive band, which is the expected position of $E R \alpha$, and other bands that did not match in size and therefore likely represented non-specific protein binding. Similar results were achieved with a third $\mathrm{ER} \alpha$ antibody (Clone C-542 from Calbiochem, data not shown). The sensitivity of ER $\alpha$ immunodetection was not improved by concentration of the protein extracts by ammonium sulfate precipitation or immunoprecipitation, by protein extraction using different lysis buffers (CelLytic MT vs RIPA buffer), by loading protein amounts of up to $200 \mu \mathrm{g} / \mathrm{lane}$, or by decreasing the dilution of the primary antibodies (to 1:250 for ER $\alpha$ F10 and 1:500 for $\mathrm{ER} \alpha \mathrm{HC}-20$; data not shown). However, $\mathrm{ER} \alpha$ protein was readily detectable in the cytoplasmic and nuclear fractions of myometrial explants cultured with the $26 \mathrm{~S}$ proteasome
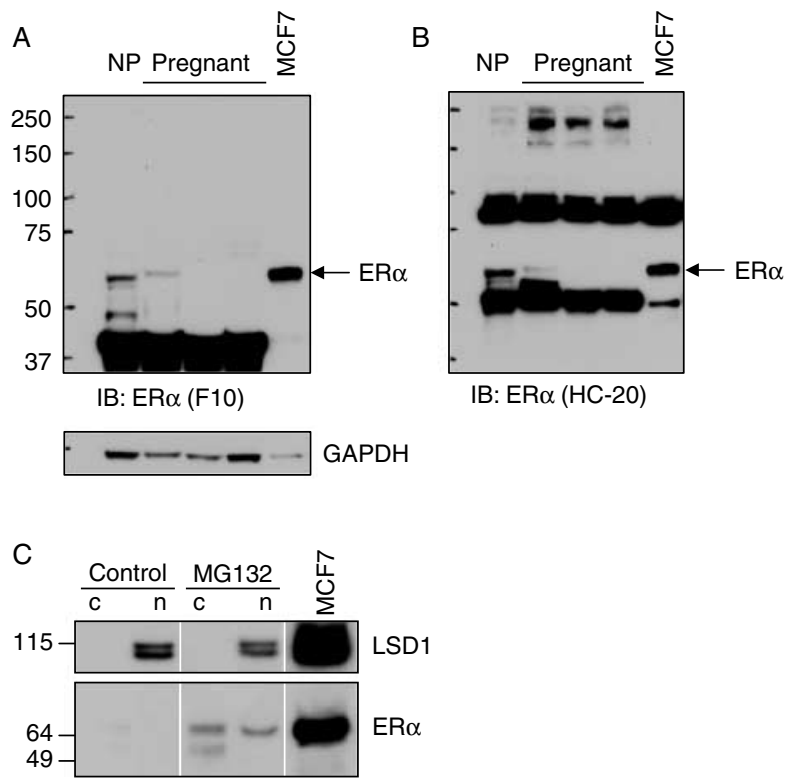

Figure 2 Representative $\mathrm{ER} \alpha$ immunoblotting in human myometrium using (A) monoclonal (F10) and (B) polyclonal (HC-20) ER $\alpha$ antibodies. $\mathrm{ER} \alpha\left(\mathrm{M}_{\mathrm{r}}\right.$ : 66000$)$ was readily detectable in nonpregnant (NP) myometrium (50 $\mu$ g total protein loaded) and MCF7 cells ( $5 \mu \mathrm{g}$ total protein) but was undetectable in two out of the three representative pregnant myometrial samples shown $(50 \mu \mathrm{g}$ total protein each). Panels $A$ and $B$ were produced from a single membrane that was probed sequentially with $\mathrm{ER} \alpha \mathrm{F} 10, \mathrm{ER} \alpha \mathrm{HC}-20$, and GAPDH antibodies. (C) ER $\alpha$ levels in cytoplasmic (c) and nuclear $(n)$ protein extracts from myometrial explants treated with vehicle or the proteasome inhibitor MG132 $(10 \mu \mathrm{m})$ for $24 \mathrm{~h}$. ER $\alpha$ immunoblotting was performed using the F10 antibody. LSD1 is a nuclear protein and served as a marker to validate the separation of cytoplasmic and nuclear proteins. The lanes were from the same gel; non-contiguous lanes are separated by white lines. The experiment was performed twice and the data shown are representative of both experiments. Numbers at the left of panels $A$ and $C$ indicate $M_{r}\left(\times 10^{-3}\right)$. 
inhibitor MG132 for $24 \mathrm{~h}$ (Fig. 2C). This suggests that ER $\alpha$ protein turnover is rapid in human myometrial tissues, leading to low steady-state ER $\alpha$ levels. Additional smaller protein bands were detected by the ER $\alpha$ antibody in the cytoplasm of MG132-treated tissue, which is similar to the data previously reported in HeLa cells (Nawaz et al. 1999) and is thought to be the result of non-proteasomal degradation.

We performed further testing of the specificity of ER $\alpha$ immunodetection, since truncated ER $\alpha$ isoforms of various sizes have been reported previously in a number of human cells and tissues following the use of the ER $\alpha$ F10 and HC-20 antibodies (Flouriot et al. 2000, Russell et al. 2000, Horvath et al. 2002, Figtree et al. 2003, Penot et al. 2005). By RNA interference, we reduced the expression of endogenous or overexpressed ER $\alpha$ protein in hTERT-HM myometrial smooth muscle cells, followed by ER $\alpha$ immunoblotting (Fig. 3). ER $\alpha$ siRNA specifically reduced the expression of full-length $66000 \mathrm{M}_{\mathrm{r}} \mathrm{ER} \alpha$ protein with no effect on other proteins detected by the ER $\alpha$ antibodies. Both endogenous and transfected ER $\alpha$ protein levels were decreased by $87-95 \%$ by ER $\alpha$ siRNA. Additionally, the sizes of the extra protein bands detected by the F10 antibody did not correspond to those detected by the HC-20 antibody, and band patterns
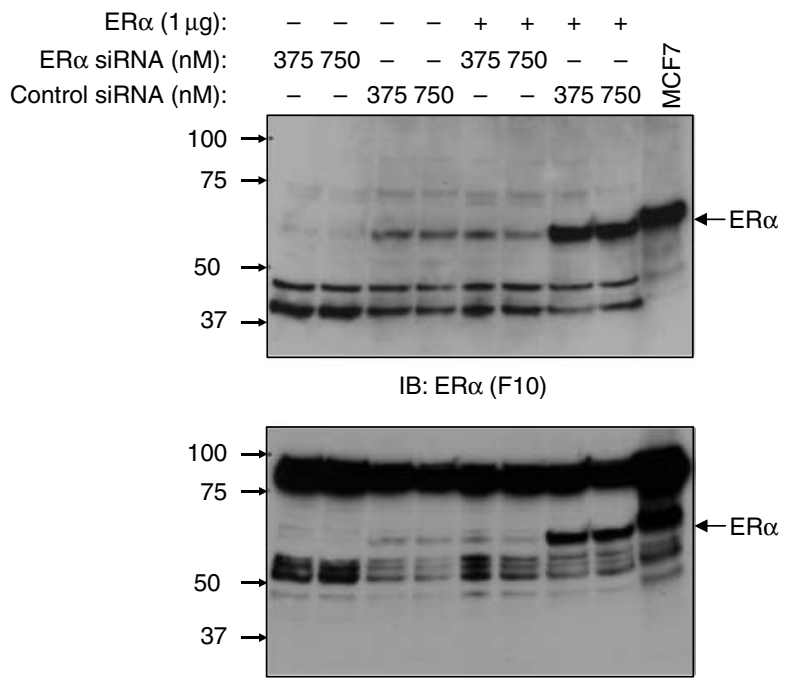

IB: $\mathrm{ER} \alpha(\mathrm{HC}-20)$

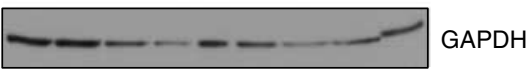

Figure 3 ER $\alpha$ siRNA in hTERT-HM myometrial smooth muscle cells. Cells were transfected with control siRNA or siRNA targeting ER $\alpha$, and some cells were co-transfected with a plasmid coding for ER $\alpha$. MCF7 breast cancer cell lysate was used as a positive control for $E R \alpha$ expression. ER $\alpha$ siRNA reduced expression of full-length $E R \alpha$ protein $\left(M_{r}\right.$ : 66 000) with no effect on other, apparently nonspecific, protein bands detected by the ER $\alpha$ antibodies. The experiment was performed twice and the data shown are representative of both experiments. The results shown were produced from a single membrane that was probed sequentially with ER $\alpha$ F10, ER $\alpha \mathrm{HC}-20$, and GAPDH antibodies; numbers and arrows at the left of the panels indicate $M_{r}\left(\times 10^{-3}\right)$. produced by these antibodies, respectively, were similar in the tissue extracts and the hTERT-HM cell extracts (Figs 2 and 3). Therefore, we have found no evidence of ER $\alpha$ splice variants in the human myometrium and conclude that immunoreactive bands other than the $66000 \mathrm{M}_{\mathrm{r}}$ full-length $\mathrm{ER} \alpha$ represent non-specific antibody binding.

GPR30 mRNA levels did not vary significantly with GA (linear regression performed on log-transformed data; $\left.r^{2}=0 \cdot 1095, \quad P=0 \cdot 143 ; n=21\right)$, but regression analysis indicated that there was a significant relationship between GPR30 mRNA expression and labor $\left(r^{2}=0 \cdot 2286, P=0 \cdot 028\right.$; $n=21$; Fig. 4A). GPR 30 mRNA abundance was significantly lower in myometrial samples from laboring compared with non-laboring women $(P=0 \cdot 0085$, $t$-test with Welch's correction for unequal variance). GPR30 protein was detected as a $55000 \mathrm{M}_{\mathrm{r}}$ immunoreactive protein band in the pregnant myometrium (Fig. 4B), as has been reported previously in human endometrium and decidua (Kolkova et al. 2010). GPR 30 protein levels did not change significantly with GA (linear regression; $r^{2}=0 \cdot 0051, P=0 \cdot 770 ; n=19$ ) or labor onset $\left(r^{2}=0 \cdot 1801, P=0 \cdot 07 ; n=19\right.$; Fig. 4C). The number of myometrial samples included in the PCR analyses is different from the sample number in the protein analyses, as not all tissue samples were of sufficient size to allow for both analyses to be performed. In 13 samples in which both GPR30 mRNA and protein were measured, there was no correlation between mRNA and protein levels (Spearman's rank correlation, $P=0 \cdot 6401)$.

$E_{2}$ stimulates rapid ERK1/2 phosphorylation in pregnant human myometrial explants

$\mathrm{E}_{2}$ at physiological concentrations (1 or $10 \mathrm{nM}$ ) stimulated phosphorylation of ERK1/2 within $30 \mathrm{~min}$ in explants of human term myometrium (Fig. 5A). PMA served as a positive control for stimulation of ERK1/2 phosphorylation (fold changes relative to vehicle controls: $1 \mathrm{nM} \mathrm{E}, 1.69 \pm 0.27$ (mean \pm s.E.M.); $10 \mathrm{nM} \mathrm{E}_{2}, 2 \cdot 02 \pm 0 \cdot 57$; PMA, $\left.1 \cdot 68 \pm 0 \cdot 33\right)$. The stimulation of ERK phosphorylation by $\mathrm{E}_{2}(10 \mathrm{nM}$ for $10 \mathrm{~min}$ ) was abrogated by pre-incubation with U0126, a highly specific inhibitor of the upstream MAPK, MAPK kinase $1 / 2(\mathrm{MEK} 1 / 2)$, or with the ER $\alpha$ antagonist ICI 182780 (Fig. 5B; fold changes relative to vehicle controls: $\mathrm{E}_{2}, 1 \cdot 48 \pm 0 \cdot 09$ (mean \pm s.E.M.); $\mathrm{E}_{2}+\mathrm{U} 0126,0 \cdot 31 \pm 0 \cdot 14$; $\left.\mathrm{E}_{2}+\mathrm{ICI}, 0 \cdot 81 \pm 0 \cdot 11\right)$. Contrary to its action on ER $\alpha$, ICI 182780 is a GPR30 agonist (Filardo et al. 2002, Lucas et al. 2010); therefore, its inhibitory effect indicates that the $\mathrm{E}_{2}$-stimulated activation of ERK/MAPK signaling in the myometrium is mediated by ER $\alpha$ and not by GPR30. Given that $E R \beta$ mRNA expression is virtually undetectable in the pregnant myometrium (Fig. 1), the involvement of this ER isoform in the observed rapid ERK signaling can be effectively ruled out. Control experiments have also shown that $E R \alpha$ mRNA continues to be expressed in myometrial explants after $24 \mathrm{~h}$ in culture, albeit at $\sim 38 \%$ of the levels in tissue snap-frozen at time 0 (data not shown). 
A

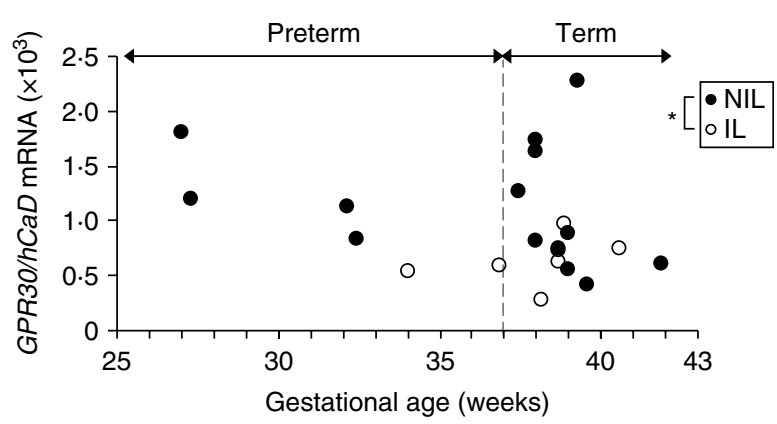

B

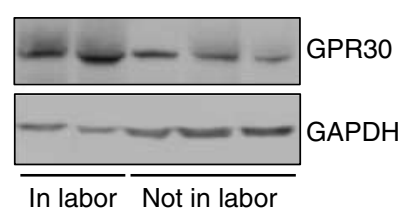

C

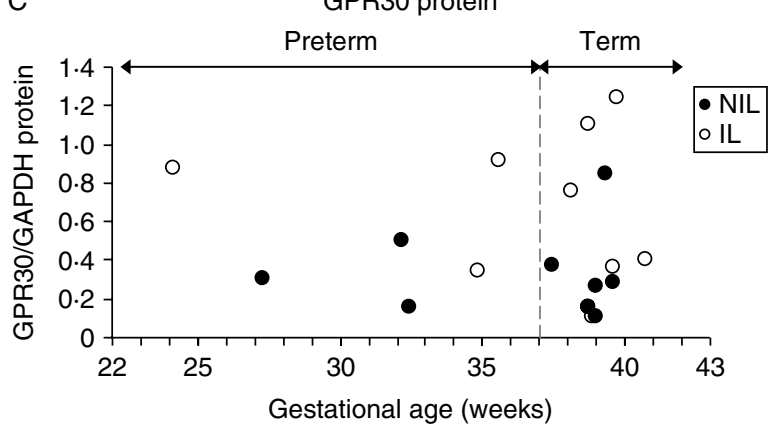

Figure 4 GPR30 expression in pregnant human myometrium. (A) GPR30 mRNA levels in individual patient samples during pregnancy; NIL, not in labor ( $n=14$; filled circles); IL, in labor ( $n=7$; open circles); ${ }^{*} P=0.0085$; $t$-test with Welch's correction for unequal variances. (B) Representative GPR30 immunoblot in term myometrium. (C) Myometrial GPR30 protein abundance; NIL, $n=9 ; \mathrm{IL}, n=10$.

\section{Effect of MEK inhibition on $E_{2}$-stimulated myometrial OXTR gene expression}

$\mathrm{E}_{2}(10 \mathrm{nM}$ for $6 \mathrm{~h})$ significantly increased OXTR mRNA expression in myometrial explants $(P<0 \cdot 05$, repeated measures ANOVA with Dunnett's post-hoc test; Fig. 5C; $1 \cdot 4 \pm 0 \cdot 16$-fold increase over vehicle controls (mean \pm S.E.M.)). This effect was blocked by pre-incubation with the MEK inhibitor U0126 (OXTR mRNA levels in explants treated with $\mathrm{E}_{2}+\mathrm{U} 0126$ were $1 \cdot 05 \pm 0 \cdot 15$-fold higher than vehicle controls, no significant difference). U0126 alone had no effect on basal OXTR gene expression $(1 \cdot 00 \pm 0 \cdot 18$-fold change compared with controls), and $h \mathrm{CaD}$ mRNA levels, used as internal reference, were not affected by any of the treatments (repeated measures ANOVA, $P=0 \cdot 4668$ ). These results indicate that the MEK/ERK signaling pathway is involved in the stimulation of OXTR gene expression by $E_{2}$.
Effect of $G A$ and labor status on ERK1/2 activation in myometrium

ERK2 phosphorylation levels increased significantly in myometrial tissues with advancing GA at collection (Fig. 6A; linear regression performed on data normalized to protein input, $\left.r^{2}=0 \cdot 1800, P=0 \cdot 0218, n=29\right)$, but there was no relationship between ERK2 phosphorylation and labor status $\left(r^{2}=0.0000, P=0.9994\right)$. ERK1 phosphorylation levels did not change significantly with either gestation $\left(r^{2}=0.0692, P=0 \cdot 1680\right)$ or labor $\left(r^{2}=0 \cdot 0473, P=0 \cdot 2573\right)$ when normalized to protein input (Fig. 6B). Total ERK protein abundance decreased significantly with advancing GA (Fig. 6C; $r^{2}=0 \cdot 2990, P=0 \cdot 0021$ ), leading to a significant increase in the ratio of both pERK2/total ERK (Fig. 6D; $\left.r^{2}=0 \cdot 3056, P=0 \cdot 002\right)$ and pERK1/total ERK (Fig. 6E; $\left.r^{2}=0 \cdot 1853, P=0 \cdot 02\right)$ with advancing gestation. There was no significant change in total ERK levels or the pERK1 or 2/total ERK ratios with labor onset. Therefore, despite a decrease in total ERK expression, the activity of the ERK pathway increases significantly in the myometrium with advancing gestation as shown by an independent increase in ERK2 phosphorylation. These data suggest that ERK activation occurs during the prelude to active labor, rather than being a consequence of labor. Phosphorylation of ERK1 appears to be increased in order to maintain consistent ERK1 activity with advancing gestation in the face of decreasing total ERK levels.

\section{Discussion}

Although estrogens are known to induce myometrial contractions and labor in animal species such as the sheep (Wu et al. 2004) and to promote the expression and/or function of contraction-associated proteins in human myometrial smooth muscle cells (Di et al. 2001, Knock et al. 2001), the genomic targets and signaling pathways controlled by estrogens in the pregnant uterus are poorly understood. Considering the importance of estrogen sensitivity in regulating the contractile capacity of the myometrium, it is surprising that ER expression in the human pregnant myometrium has not been systematically characterized. Our qRT-PCR data indicate that ER $\alpha$ is the most abundantly expressed ER in the myometrium during pregnancy, at least at the level of gene expression. ER $\alpha$ mRNA abundance was significantly higher in the myometrial tissues from women in labor compared with quiescent myometrium, which is similar to data we have reported previously (Mesiano et al. 2002, Bisits et al. 2005). Myometrial ER $\beta$ mRNA levels were extremely low. While these data are in conflict with a previous report showing ER $\beta$ expression in term, non-laboring myometrium (Wu et al. 2000), they are in concurrence with our previously published data, which showed extremely low myometrial $E R \beta$ mRNA levels in a different population of pregnant women and using different PCR primers 
A
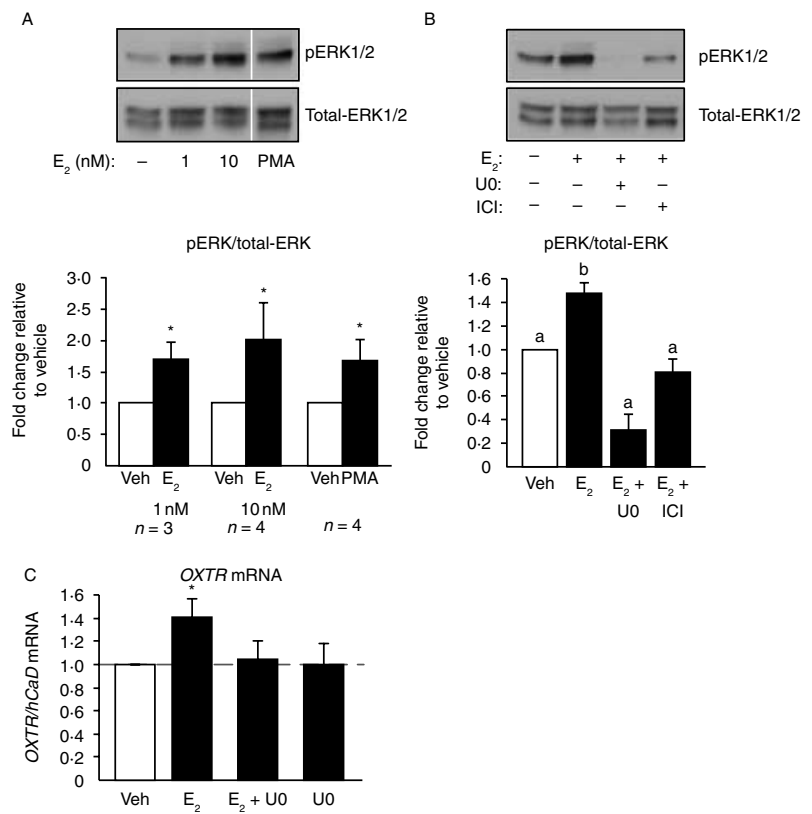

Figure 5 (A) Estradiol $\left(E_{2} ; 1\right.$ or $10 \mathrm{~nm}$ ) treatment for $30 \mathrm{~min}$ stimulated phosphorylation of ERK $1 / 2$ in human myometrial explants, compared to vehicle-treated controls. PMA (100 nm) served as a positive control for stimulation of ERK phosphorylation. The lanes were from the same gel but the PMA lane was noncontiguous. Phospho-ERK levels were quantified relative to total ERK levels and the results are shown as mean + S.E.M., normalized to vehicle-treated controls. ${ }^{*} P<0 \cdot 05$, paired $t$-test comparing treatment and control. Fold changes relative to vehicle controls: $1 \mathrm{nM}$ $\mathrm{E}_{2}, 1 \cdot 69 \pm 0 \cdot 27$ (mean \pm s.E.M.); $10 \mathrm{nM} \mathrm{E}, 2 \cdot 02 \pm 0 \cdot 57$; PMA, $1 \cdot 68 \pm 0 \cdot 33$; (B) $E_{2}(10 \mathrm{~nm}$ for $10 \mathrm{~min})$ stimulated ERK1/2 phosphorylation, which was inhibited by pre-treatment with the MEK inhibitor U0126 $(10 \mu \mathrm{M})$ or the estrogen receptor antagonist ICI $182780(1 \mu \mathrm{M})$. The same pattern was seen when explants were stimulated for $30 \mathrm{~min}$ (data not shown). Phospho-ERK levels, relative to total ERK levels, are shown as mean + S.E.M., normalized to vehicle-treated controls. Different letters denote significant differences between groups $(P<0 \cdot 05$; repeated measures ANOVA followed by paired $t$-tests with Bonferroni's correction for multiple comparisons; $n=4$ independent experiments; fold changes relative to vehicle controls: $E_{2}, 1 \cdot 48 \pm 0.09$ (mean \pm S.E.M.); $E_{2}+U 0126$, $0 \cdot 31 \pm 0 \cdot 14 ; \mathrm{E}_{2}+\mathrm{ICI}, 0 \cdot 81 \pm 0 \cdot 11$ ). (C) OXTR mRNA levels in term myometrial explants were increased by stimulation with $E_{2}(10 \mathrm{~nm}$; for $6 \mathrm{~h}$ ) and were reduced to basal levels by pre-incubation with the MEK inhibitor U0126 $(10 \mu \mathrm{M})$. Data are from myometrial tissues obtained from four different women and are presented as mean + S.E.M. and normalized to vehicle-treated controls. Fold changes relative to vehicle controls: $E_{2}, 1 \cdot 4 \pm 0 \cdot 16$ (mean \pm S.E.M.);

$\mathrm{E}_{2}+\mathrm{U} 0126,1 \cdot 05 \pm 0 \cdot 15 ; \mathrm{U} 0126,1 \cdot 00 \pm 0 \cdot 18 .{ }^{*} P<0 \cdot 05$ (vehicle vs $\mathrm{E}_{2}$; repeated measures ANOVA with Dunnett's post-hoc test).

(Mesiano et al. 2002). In both cases, the validity of our $E R \beta$ qRT-PCR assays was confirmed by measuring $E R \beta$ mRNA in T47D cells. While we observed robust expression of $E R \alpha$ mRNA in the pregnant myometrium, ER $\alpha$ protein expression was virtually undetectable by immunoblotting with three commercially available ER $\alpha$ antibodies. Similar results have been reported previously (Geimonen et al. 1998).
Our data using the proteasome inhibitor MG132, however, indicate that $E R \alpha$ mRNA is indeed translated into ER $\alpha$ protein in the pregnant myometrium, but that this protein is targeted for rapid turnover through the ubiquitin-proteasome pathway in the myometrium leading to low steady-state levels. Similar data have been reported for ER $\alpha$ in human breast cancer cell lines (Chu et al. 2007) and HeLa cells (Nawaz et al. 1999).

The discovery that GPR30 is a membrane-associated ER added a novel dimension to the complexity of estrogen signaling. Controversy exists, however, regarding whether GPR30 is truly an ER (Levin 2009, Langer et al. 2010), with several studies showing that GPR30 directly binds $\mathrm{E}_{2}$ (Revankar et al. 2005, Thomas et al. 2005, Thomas \& Dong 2006) and another study showing that it does not (Otto et al. 2008). It also remains unclear whether GPR 30 localizes to the plasma membrane (Funakoshi et al. 2006, Filardo et al. 2007) or to the endoplasmic reticulum (Revankar et al. 2005, Otto et al. 2008). GPR 30 clearly mediates components of estrogen signaling, as evidenced by multiple studies that confer estrogen responsiveness by inducing GPR30 expression or repress estrogen signaling via GPR30 knockdown or inhibition (reviewed in Prossnitz \& Maggiolini (2009) and Maggiolini \& Picard (2010)). On balance, the current weight of evidence suggests that GPR30 is most likely a bona fide $\mathrm{ER}$, and our data are similar to a recent report showing that GPR $30 \mathrm{mRNA}$ and protein are present in the term pregnant human myometrium (Maiti et al. 2011). The role of GPR30 in reproduction and especially uterine function during pregnancy is unknown; however, GPR30 knockout mice have unimpaired fertility, retain normal uterine estrogenic responses, and appear to have normal pregnancies and parturition (Wang et al. 2008, Isensee et al. 2009, Otto et al. 2009, Windahl et al. 2009). Current data therefore suggest that the role of GPR30 in mediating estrogen actions in the pregnant myometrium is minimal. We have shown that $\mathrm{E}_{2}$-induced ERK1/2 phosphorylation was inhibited by ICI 182780 in the myometrium. ICI 182780 inhibits ER $\alpha$ and ER $\beta$ signaling but acts as an agonist on GPR30 (Filardo et al. 2002, Lucas et al. 2010). Our results therefore indicate that $\mathrm{E}_{2}$-stimulated ERK1/2 phosphorylation in myometrial explants was mediated by a classical ER and not GPR30. Owing to the lack of ER $\beta$ expression in the pregnant human myometrium, we reason that this rapid effect was mediated by ER $\alpha$. While Maiti et al. (2011) showed that a specific activator of GPR30, G1, stimulated ERK1/2 phosphorylation in human myometrial explants, their study did not examine the contribution of GPR30 to $E_{2}$ action. Rapid activation of non-genomic signaling via $\mathrm{ER} \alpha$ has been reported in other estrogen-responsive tissues and appears to be cell-type specific (Vasudevan \& Pfaff 2008); however, this is a novel signaling mechanism in the pregnant myometrium. Studies using ER $\alpha$ inhibition or knockdown techniques, or conversely the induction of ER $\alpha$ expression, have demonstrated the reliance on this receptor for non-genomic estrogen signaling in vascular endothelial cells (Chen et al. 1999, Lu et al. 2004), 

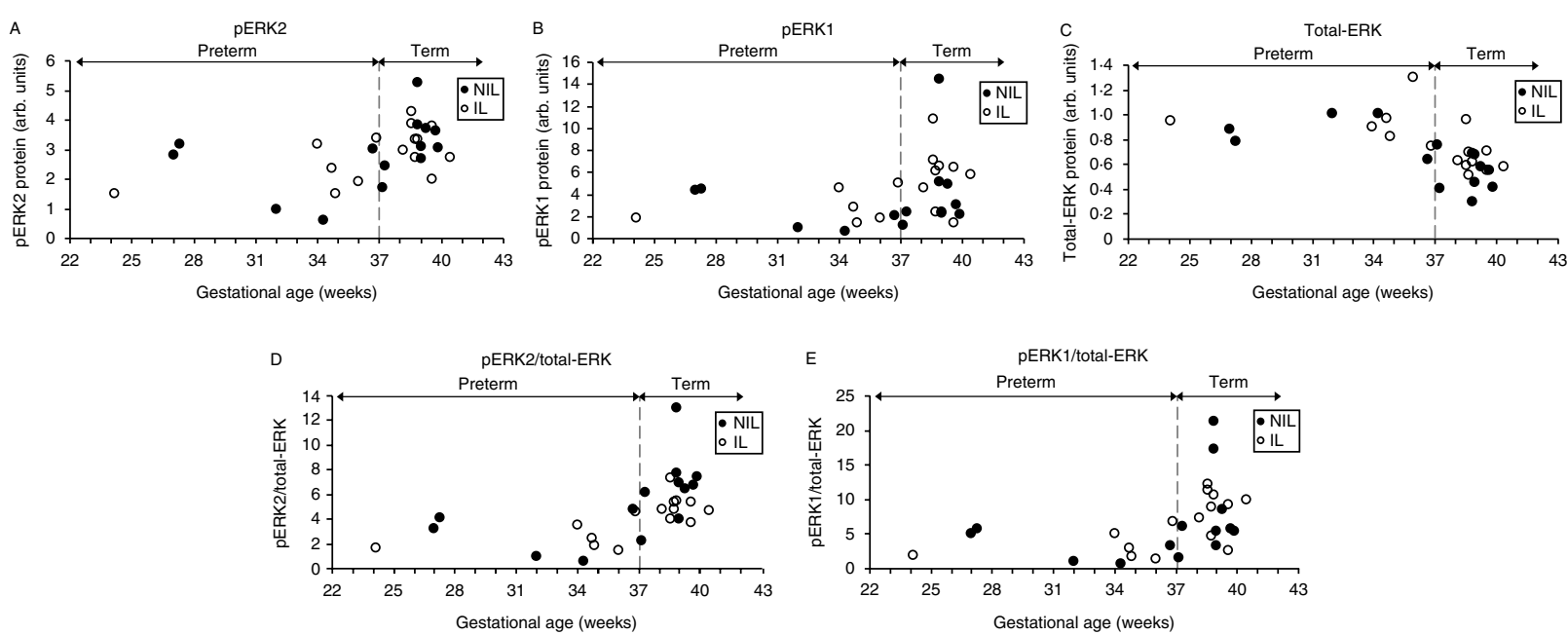

Figure 6 Total and phosphorylated ERK levels in pregnant human myometrium. (A) pERK2 protein levels (expressed as arbitrary densitometry units); (B) pERK1 protein levels; (C) total ERK protein levels; (D) pERK2/total ERK protein ratio; and, (E) pERK1/total ERK protein ratio. For all panels, NIL, not in labor ( $n=14$; filled circles); IL, in labor $(n=15$; open circles). Regression analysis showed that myometrial pERK2 abundance increased significantly with advancing gestational age $(P=0 \cdot 022)$ while total ERK abundance decreased significantly $(P=0 \cdot 002)$, and there was no significant change in pERK1 abundance. When normalized to total ERK expression, there was a significant effect of gestational age on both pERK1 $(P=0.02)$ and pERK2 $(P=0.002)$ levels. There was no effect of labor on total or phosphorylated ERK abundance or on the pERK1 or 2/total ERK protein ratios.

CHO cells (Razandi et al. 1999), and breast cancer cells (Pedram et al. 2006, Madak-Erdogan et al. 2008). Additionally, cells from $E R \alpha / \beta$ knockout mice have impaired nongenomic $\mathrm{E}_{2}$ signaling compared with cells from wild-type mice (Abraham et al. 2004, Pedram et al. 2006). Our data support the concept that, upon ligand activation, ER $\alpha$ interacts directly with cytoplasmic signaling molecules leading to activation of the ERK/MAPK cascade in the pregnant human myometrium.

Our findings support the hypothesis that extranuclear actions of $\mathrm{E}_{2}$ are important for the induction of procontraction gene expression in the myometrium. The MEK inhibitor U0126 completely blocked the ability of $E_{2}$ to stimulate increased OXTR mRNA expression in myometrial explants (Fig. 5C). These data provide strong evidence that the MEK/ERK cascade is the principal pathway through which $\mathrm{E}_{2}$ increases OXTR mRNA expression in our experimental system. We have not measured changes in the OXTR protein levels in this study, although we acknowledge the importance of measuring protein expression to appraise the functional consequences of gene expression changes. OXTR protein turnover is expected to be slower than mRNA turnover and is potentially under additional regulation, and we have not validated our explant culture system for the conditions required to evaluate changes in protein levels in response to $\mathrm{E}_{2}$, which would include longer incubation times. The focus of this study was instead the regulation of the OXTR gene by $\mathrm{E}_{2}$. There is no complete ERE in the human OXTR promoter (Gimpl \& Fahrenholz 2001), which is in concurrence with the proposal that $\mathrm{E}_{2}$ stimulates OXTR mRNA expression via an indirect mechanism. It has previously been shown that $25 \%$ of all $\mathrm{E}_{2}$-responsive genes in MCF7 cells are altered via activation of non-genomic signaling mediated by ER $\alpha$ (Madak-Erdogan et al. 2008). It will be important in future studies to determine the full spectrum of estrogen-responsive genes and their protein products in the myometrium, in particular those related to contractility, and to discover which of these genes are mediated via direct genomic ER $\alpha$ transcriptional activity vs indirect, non-genomic pathways. This information could influence the design of therapeutics that target the pro-contractile effect of $E_{2}$ in the myometrium to treat and/or prevent preterm labor.

Myometrial ERK2 phosphorylation increased significantly with advancing GA in accordance with previously reported results in the pregnant rat uterus (Oldenhof et al. 2002, Serrano-Sanchez et al. 2008). We observed no change in ERK1/2 phosphorylation in the myometrium with labor, which agrees with a previous report on the rat myometrium (Oldenhof et al. 2002) but differs from that of Li et al. (2003) who reported increased ERK2 phosphorylation in the rat uterus during labor. While total ERK protein levels do not appear to change in the rat myometrium with pregnancy or labor ( $\mathrm{Li}$ et al. 2003), we saw a decrease in total ERK in human myometrium with advancing gestation. However, the increase in phospho-ERK2 levels, measured independent of total ERK levels, indicates that the activity of this pathway indeed increases with advancing gestation. Paul et al. (2011) reported that total ERK2 protein levels in human myometrium increased slightly with labor onset at term and that there was no change in the ratio of pERK2/total ERK2, which largely agrees with our data, although we found no significant change in total ERK protein following labor onset. Our data are the first report of ERK1/2 phosphorylation levels in relation to advancing GA in the human myometrium. Given 
the elevated levels of myometrial ERK phosphorylation in late gestation, and the delayed labor caused by inhibition of the ERK pathway in RU486-treated rats ( $\mathrm{Li}$ et al. 2004), we hypothesize that this is an important signaling pathway that is activated as part of the parturition process. Increased ERK phosphorylation may remodel the myometrium into a contractile phenotype by modulating gene expression via activation of transcription factors (Yoon \& Seger 2006) and/ or by altering the contractile apparatus via phosphorylation of cytoskeletal proteins including $\mathrm{hCaD}$, paxillin, and $\mathrm{FAK}$ (Yoon \& Seger 2006). While ERK proteins may become phosphorylated in response to many stimuli in addition to estrogens, we hypothesize that ER $\alpha$-mediated estrogen activation in the uterus may be partially responsible for stimulating the elevated levels of ERK signaling observed at late gestation. Thus, we propose that estrogenic activity in the human pregnant myometrium is predominantly mediated by $E R \alpha$, which affects gene expression by a combination of nongenomic and genomic signaling. The novel membrane ER, GPR 30, is also expressed in the pregnant human myometrium, but its contribution to mediating estrogen action appears minor. Nevertheless, it is important to consider the multiple ERs and pathways of receptor action in determining the molecular mechanisms by which estrogens regulate myometrial contractility in pregnant women.

\section{Declaration of interest}

The authors declare that there is no conflict of interest that could be perceived as prejudicing the impartiality of the research reported.

\section{Funding}

This work was supported by the March of Dimes Birth Defect Foundation (grant 21-FY10-173 to S M). T W was supported by the Ella Macknight Memorial Scholarship (2009-10) from the RANZCOG Research Foundation.

\section{References}

Abraham IM, Todman MG, Korach KS \& Herbison AE 2004 Critical in vivo roles for classical estrogen receptors in rapid estrogen actions on intracellular signaling in mouse brain. Endocrinology 145 3055-3061. (doi:10.1210/en. 2003-1676)

Barletta F, Wong CW, McNally C, Komm BS, Katzenellenbogen B \& Cheskis BJ 2004 Characterization of the interactions of estrogen receptor and MNAR in the activation of cSrc. Molecular Endocrinology 18 1096-1108. (doi:10.1210/me.2003-0335)

Benassayag C, Leroy MJ, Rigourd V, Robert B, Honore JC, Mignot TM, Vacher-Lavenu MC, Chapron C \& Ferre F 1999 Estrogen receptors $(\mathrm{ER} \alpha / \mathrm{ER} \beta)$ in normal and pathological growth of the human myometrium: pregnancy and leiomyoma. American Journal of Physiology. Endocrinology and Metabolism 276 E1112-E1118.

Bisits AM, Smith R, Mesiano S, Yeo G, Kwek K, MacIntyre D \& Chan EC 2005 Inflammatory aetiology of human myometrial activation tested using directed graphs. PLoS Computational Biology 1 132-136. (doi:10.1371/ journal.pcbi.0010019)
Chen Z, Yuhanna IS, Galcheva-Gargova Z, Karas RH, Mendelsohn ME \& Shaul PW 1999 Estrogen receptor $\boldsymbol{\alpha}$ mediates the nongenomic activation of endothelial nitric oxide synthase by estrogen. Journal of Clinical Investigation 103 401-406. (doi:10.1172/JCI5347)

Chu I, Arnaout A, Loiseau S, Sun J, Seth A, McMahon C, Chun K, Hennessy B, Mills GB, Nawaz Z et al. 2007 Src promotes estrogen-dependent estrogen receptor $\alpha$ proteolysis in human breast cancer. Journal of Clinical Investigation 117 2205-2215. (doi:10.1172/JCI21739)

Condon J, Yin S, Mayhew B, Word RA, Wright WE, Shay JW \& Rainey WE 2002 Telomerase immortalization of human myometrial cells. Biology of Reproduction 67 506-514. (doi:10.1095/biolreprod67.2.506)

Dechering K, Boersma C \& Mosselman S 2000 Estrogen receptors $\alpha$ and $\beta$ : two receptors of a kind? Current Medicinal Chemistry 7 561-576.

De Hertogh R, Thomas K, Bietlot Y, Vanderheyden I \& Ferin J 1975 Plasma levels of unconjugated estrone, estradiol and estriol and of HCS throughout pregnancy in normal women. Journal of Clinical Endocrinology and Metabolism 40 93-101. (doi:10.1210/jcem-40-1-93)

Di WL, Lachelin GC, McGarrigle HH, Thomas NS \& Becker DL 2001 Oestriol and oestradiol increase cell to cell communication and connexin 43 protein expression in human myometrium. Molecular Human Reproduction $\mathbf{7}$ 671-679. (doi:10.1093/molehr/7.7.671)

Figtree GA, McDonald D, Watkins H \& Channon KM 2003 Truncated estrogen receptor $\alpha 46-\mathrm{kDa}$ isoform in human endothelial cells: relationship to acute activation of nitric oxide synthase. Circulation 107 120-126. (doi:10.1161/01.CIR.0000043805.11780.F5)

Filardo EJ, Quinn JA, Frackelton AR Jr \& Bland KI 2002 Estrogen action via the $\mathrm{G}$ protein-coupled receptor, GPR 30: stimulation of adenylyl cyclase and cAMP-mediated attenuation of the epidermal growth factor receptorto-MAPK signaling axis. Molecular Endocrinology 16 70-84. (doi:10.1210/ me.16.1.70)

Filardo E, Quinn J, Pang Y, Graeber C, Shaw S, Dong J \& Thomas P 2007 Activation of the novel estrogen receptor $\mathrm{G}$ protein-coupled receptor 30 (GPR30) at the plasma membrane. Endocrinology 148 3236-3245. (doi:10. 1210/en.2006-1605)

Flouriot G, Brand H, Denger S, Metivier R, Kos M, Reid G, Sonntag-Buck $\mathrm{V} \&$ Gannon F 2000 Identification of a new isoform of the human estrogen receptor- $\alpha(\mathrm{hER}-\alpha)$ that is encoded by distinct transcripts and that is able to repress hER- $\alpha$ activation function 1. EMBO Journal 19 4688-4700. (doi:10.1093/emboj/19.17.4688)

Fox EM, Andrade J \& Shupnik MA 2009 Novel actions of estrogen to promote proliferation: integration of cytoplasmic and nuclear pathways. Steroids 74 622-627. (doi:10.1016/j.steroids.2008.10.014)

Funakoshi T, Yanai A, Shinoda K, Kawano MM \& Mizukami Y 2006 $\mathrm{G}$ protein-coupled receptor 30 is an estrogen receptor in the plasma membrane. Biochemical and Biophysical Research Communications 346 904-910. (doi:10.1016/j.bbrc.2006.05.191)

Geimonen E, Jiang W, Ali M, Fishman GI, Garfield RE \& Andersen J 1996 Activation of protein kinase $\mathrm{C}$ in human uterine smooth muscle induces connexin-43 gene transcription through an AP-1 site in the promoter sequence. Journal of Biological Chemistry 271 23667-23674. (doi:10.1074/ jbc.271.39.23667)

Geimonen E, Boylston E, Royek A \& Andersen J 1998 Elevated connexin-43 expression in term human myometrium correlates with elevated c-Jun expression and is independent of myometrial estrogen receptors. Journal of Clinical Endocrinology and Metabolism 83 1177-1185. (doi:10.1210/jc.83.4. 1177)

Gimpl G \& Fahrenholz F 2001 The oxytocin receptor system: structure, function, and regulation. Physiological Reviews 81 629-683.

Horvath G, Leser G, Helou K \& Henriksson M 2002 Function of the exon 7 deletion variant estrogen receptor a protein in an estradiol-resistant, tamoxifen-sensitive human endometrial adenocarcinoma grown in nude mice. Gynecologic Oncology 84 271-279. (doi:10.1006/gyno.2001.6509)

Isensee J, Meoli L, Zazzu V, Nabzdyk C, Witt H, Soewarto D, Effertz K, Fuchs H, Gailus-Durner V, Busch D et al. 2009 Expression pattern of $\mathrm{G}$ protein-coupled receptor 30 in LacZ reporter mice. Endocrinology 150 1722-1730. (doi:10.1210/en.2008-1488)

Kilarski WM, Fu X, Backstrom T, Roomans GM \& Ulmsten U 1996 Progesterone, oestradiol and oxytocin and their in vitro effect on 
maintaining the number of gap junction plaques in human myometrium at term. Acta Physiologica Scandinavica 157 461-469. (doi:10.1046/j.1365201X.1996.500247000.x)

Kilarski WM, Hongpaisan J, Semik D \& Roomans GM 2000 Effect of progesterone and oestradiol on expression of connexin 43 in cultured human myometrium cells. Folia Histochemica et Cytobiologica 38 3-9.

Knock GA, Tribe RM, Hassoni AA \& Aaronson PI 2001 Modulation of potassium current characteristics in human myometrial smooth muscle by 17 $\beta$-estradiol and progesterone. Biology of Reproduction 64 1526-1534. (doi:10.1095/biolreprod64.5.1526)

Kolkova Z, Noskova V, Ehinger A, Hansson S \& Casslen B 2010 G proteincoupled receptor 1 (GPER, GPR 30) in normal human endometrium and early pregnancy decidua. Molecular Human Reproduction 16 743-751. (doi:10.1093/molehr/gaq043)

Kumar P, Wu Q, Chambliss KL, Yuhanna IS, Mumby SM, Mineo C, Tall GG \& Shaul PW 2007 Direct interactions with G $\alpha$ i and G $\beta \gamma$ mediate nongenomic signaling by estrogen receptor $\alpha$. Molecular Endocrinology 21 1370-1380. (doi:10.1210/me.2006-0360)

Langer G, Bader B, Meoli L, Isensee J, Delbeck M, Noppinger PR \& Otto C 2010 A critical review of fundamental controversies in the field of GPR30 research. Steroids 75 603-610. (doi:10.1016/j.steroids.2009.12. 006)

Laudanski P, Redzko S, Przepiesc J, Koda M, Wolczynski S, Sulkowski S \& Urban J 2004 Expression of estrogen receptors $\alpha$ and $\beta$ in term human myometrium. Reproductive Biology 4 305-311.

Levin ER 2009 G protein-coupled receptor 30: estrogen receptor or collaborator? Endocrinology 150 1563-1565. (doi:10.1210/en.2008-1759)

Li Y, Je HD, Malek S \& Morgan KG 2003 ERK1/2-mediated phosphorylation of myometrial caldesmon during pregnancy and labor. American Journal of Physiology. Regulatory, Integrative and Comparative Physiology 284 R192-R199. (doi:10.1152/ajpregu.00290.2002)

Li Y, Je HD, Malek S \& Morgan KG 2004 Role of ERK1/2 in uterine contractility and preterm labor in rats. American Journal of Physiology. Regulatory, Integrative and Comparative Physiology 287 R328-R335. (doi:10. 1152/ajpregu.00042.2004)

Livak KJ \& Schmittgen TD 2001 Analysis of relative gene expression data using real-time quantitative PCR and the $2^{-\Delta \Delta C_{\mathrm{T}}}$ method. Methods $\mathbf{4 5}$ 402-408. (doi:10.1006/meth.2001.1262)

Lu Q, Pallas DC, Surks HK, Baur WE, Mendelsohn ME \& Karas RH 2004 Striatin assembles a membrane signaling complex necessary for rapid, nongenomic activation of endothelial NO synthase by estrogen receptor $\alpha$. PNAS 101 17126-17131. (doi:10.1073/pnas. 0407492101)

Lucas TF, Royer C, Siu ER, Lazari MF \& Porto CS 2010 Expression and signaling of $\mathrm{G}$ protein-coupled estrogen receptor 1 (GPER) in rat sertoli cells. Biology of Reproduction 83 307-317. (doi:10.1095/biolreprod.110. 084160)

Lye SJ, Nicholson BJ, Mascarenhas M, MacKenzie L \& Petrocelli T 1993 Increased expression of connexin-43 in the rat myometrium during labor is associated with an increase in the plasma estrogen:progesterone ratio. Endocrinology 132 2380-2386. (doi:10.1210/en.132.6.2380)

Madak-Erdogan Z, Kieser KJ, Kim SH, Komm B, Katzenellenbogen JA \& Katzenellenbogen BS 2008 Nuclear and extranuclear pathway inputs in the regulation of global gene expression by estrogen receptors. Molecular Endocrinology 22 2116-2127. (doi:10.1210/me.2008-0059)

Maggiolini M \& Picard D 2010 The unfolding stories of GPR30, a new membrane-bound estrogen receptor. Journal of Endocrinology 204 105-114. (doi:10.1677/JOE-09-0242)

Maiti K, Paul JW, Read M, Chan EC, Riley SC, Nahar P \& Smith R 2011 G-1-activated membrane estrogen receptors mediate increased contractility of the human myometrium. Endocrinology 152 2448-2455. (doi:10.1210/ en.2010-0979)

Mesiano S, Chan EC, Fitter JT, Kwek K, Yeo G \& Smith R 2002 Progesterone withdrawal and estrogen activation in human parturition are coordinated by progesterone receptor A expression in the myometrium. Journal of Clinical Endocrinology and Metabolism 87 2924-2930. (doi:10.1210/ jc.87.6.2924)
Migliaccio A, Di Domenico M, Castoria G, de Falco A, Bontempo P, Nola E \& Auricchio F 1996 Tyrosine kinase/p21ras/MAP-kinase pathway activation by estradiol-receptor complex in MCF-7 cells. EMBO Journal 15 1292-1300.

Nawaz Z, Lonard DM, Dennis AP, Smith CL \& O’Malley BW 1999 Proteasome-dependent degradation of the human estrogen receptor. PNAS 96 1858-1862. (doi:10.1073/pnas.96.5.1858)

Nissenson R, Fluoret G \& Hechter O 1978 Opposing effects of estradiol and progesterone on oxytocin receptors in rabbit uterus. PNAS 75 2044-2048. (doi:10.1073/pnas.75.4.2044)

Oldenhof AD, Shynlova OP, Liu M, Langille BL \& Lye SJ 2002 Mitogenactivated protein kinases mediate stretch-induced $\mathrm{c}$-fos mRNA expression in myometrial smooth muscle cells. American Journal of Physiology. Cell Physiology 283 C1530-C1539. (doi:10.1152/ajpcell.00607.2001)

Otto C, Rohde-Schulz B, Schwarz G, Fuchs I, Klewer M, Brittain D, Langer G, Bader B, Prelle K, Nubbemeyer R et al. 2008 G protein-coupled receptor 30 localizes to the endoplasmic reticulum and is not activated by estradiol. Endocrinology 149 4846-4856. (doi:10.1210/en.2008-0269)

Otto C, Fuchs I, Kauselmann G, Kern H, Zevnik B, Andreasen P, Schwarz G, Altmann H, Klewer M, Schoor M et al. 2009 GPR30 does not mediate estrogenic responses in reproductive organs in mice. Biology of Reproduction 80 34-41. (doi:10.1095/biolreprod.108.071175)

Paul J, Maiti K, Read M, Hure A, Smith J, Chan EC \& Smith R 2011 Phasic phosphorylation of caldesmon and ERK1/2 during contractions in human myometrium. PLoS ONE 6 e21542. (doi:10.1371/journal.pone.0021542)

Pedram A, Razandi M \& Levin ER 2006 Nature of functional estrogen receptors at the plasma membrane. Molecular Endocrinology 20 1996-2009. (doi:10.1210/me.2005-0525)

Penot G, Le Peron C, Merot Y, Grimaud-Fanouillere E, Ferriere F, Boujrad N, Kah O, Saligaut C, Ducouret B, Metivier R et al. 2005 The human estrogen receptor-a isoform hERa46 antagonizes the proliferative influence of hERa66 in MCF7 breast cancer cells. Endocrinology 146 5474-5484. (doi:10. 1210/en.2005-0866)

Pepe GJ \& Albrecht ED 1995 Actions of placental and fetal adrenal steroid hormones in primate pregnancy. Endocrine Reviews 16 608-648. (doi:10. 1210/edrv-16-5-608)

Petrocelli T \& Lye SJ 1993 Regulation of transcripts encoding the myometrial gap junction protein, connexin-43, by estrogen and progesterone. Endocrinology 133 284-290. (doi:10.1210/en.133.1.284)

Pinto RM, Lerner U, Glauberman M \& Pontelli H 1966 Influence of estradiol-17- $\beta$ upon the oxytocic action of oxytocin in the pregnant human uterus. American Journal of Obstetrics and Gynecology 96 857-862.

Pinto RM, Lerner U, Pontelli H \& Rabow W 1967 Effect of estradiol-17- $\beta$ on oxytocin induced contraction of the three separate layers of human pregnant myometrium. American Journal of Obstetrics and Gynecology 97 881-887.

Prossnitz ER \& Maggiolini M 2009 Mechanisms of estrogen signaling and gene expression via GPR 30. Molecular and Cellular Endocrinology 308 32-38. (doi:10.1016/j.mce.2009.03.026)

Razandi M, Pedram A, Greene GL \& Levin ER 1999 Cell membrane and nuclear estrogen receptors (ERs) originate from a single transcript: studies of ER $\alpha$ and ER $\beta$ expressed in Chinese hamster ovary cells. Molecular Endocrinology 13 307-319. (doi:10.1210/me.13.2.307)

Razandi M, Pedram A, Park ST \& Levin ER 2003 Proximal events in signaling by plasma membrane estrogen receptors. Journal of Biological Chemistry 278 2701-2712. (doi:10.1074/jbc.M205692200)

Revankar CM, Cimino DF, Sklar LA, Arterburn JB \& Prossnitz ER 2005 A transmembrane intracellular estrogen receptor mediates rapid cell signaling. Science 307 1625-1630. (doi:10.1126/science.1106943)

Ruijter JM, Ramakers C, Hoogaars WMH, Karlen Y, Bakker O, van den Hoff MJB \& Moorman AFM 2009 Amplification efficiency: linking baseline and bias in the analysis of quantitative PCR data. Nucleic Acids Research 37 e 45. (doi:10.1093/nar/gkp045)

Russell KS, Haynes MP, Sinha D, Clerisme E \& Bender JR 2000 Human vascular endothelial cells contain membrane binding sites for estradiol, which mediate rapid intracellular signaling. PNAS 97 5930-5935. (doi:10. 1073/pnas.97.11.5930) 
Serrano-Sanchez M, Tanfin Z \& Leiber D 2008 Signaling pathways involved in sphingosine kinase activation and sphingosine-1-phosphate release in rat myometrium in late pregnancy: role in the induction of cyclooxygenase 2 . Endocrinology 149 4669-4679. (doi:10.1210/en.2007-1756)

Smith R, Smith JI, Shen X, Engel PJ, Bowman ME, McGrath SA, Bisits AM, McElduff P, Giles WB \& Smith DW 2009 Patterns of plasma corticotropinreleasing hormone, progesterone, estradiol, and estriol change and the onset of human labor. Journal of Clinical Endocrinology and Metabolism 94 2066-2074. (doi:10.1210/jc.2008-2257)

Song RX, McPherson RA, Adam L, Bao Y, Shupnik M, Kumar R \& Santen RJ 2002 Linkage of rapid estrogen action to MAPK activation by ER $\alpha-$ Shc association and Shc pathway activation. Molecular Endocrinology 16 116-127. (doi:10.1210/me.16.1.116)

Song RX, Barnes CJ, Zhang Z, Bao Y, Kumar R \& Santen RJ 2004 The role of Shc and insulin-like growth factor 1 receptor in mediating the translocation of estrogen receptor a to the plasma membrane. PNAS 101 2076-2081. (doi:10.1073/pnas.0308334100)

Thomas P \& Dong J 2006 Binding and activation of the seven-transmembrane estrogen receptor GPR30 by environmental estrogens: a potential novel mechanism of endocrine disruption. Journal of Steroid Biochemistry and Molecular Biology 102 175-179. (doi:10.1016/j.jsbmb.2006.09.017)

Thomas P, Pang Y, Filardo EJ \& Dong J 2005 Identity of an estrogen membrane receptor coupled to a $\mathrm{G}$ protein in human breast cancer cells. Endocrinology 146 624-632. (doi:10.1210/en.2004-1064)

Vasudevan N \& Pfaff DW 2008 Non-genomic actions of estrogens and their interaction with genomic actions in the brain. Frontiers in Neuroendocrinology 29 238-257. (doi:10.1016/j.yfrne.2007.08.003)

Wang C, Dehghani B, Magrisso IJ, Rick EA, Bonhomme E, Cody DB, Elenich LA, Subramanian S, Murphy SJ, Kelly MJ et al. 2008 GPR30 contributes to estrogen-induced thymic atrophy. Molecular Endocrinology 22 636-648. (doi:10.1210/me.2007-0359)
Warner M, Nilsson S \& Gustafsson JA 1999 The estrogen receptor family. Current Opinion in Obstetrics and Gynecology 11 249-254. (doi:10.1097/ 00001703-199906000-00003)

Windahl SH, Andersson N, Chagin AS, Martensson UE, Carlsten H, Olde B, Swanson C, Moverare-Skrtic S, Savendahl L, Lagerquist MK et al. 2009 The role of the G protein-coupled receptor GPR30 in the effects of estrogen in ovariectomized mice. American Journal of Physiology. Endocrinology and Metabolism 296 E490-E496. (doi:10.1152/ajpendo. 90691. 2008)

Winkler M, Kemp B, Classen-Linke I, Fischer DC, Zlatinsi S, Neulen J, Beier HM \& Rath W 2002 Estrogen receptor a and progesterone receptor A and $\mathrm{B}$ concentration and localization in the lower uterine segment in term parturition. Journal of the Society for Gynecologic Investigation 9 226-232. (doi:10.1016/S1071-5576(02)00156-9)

Wu JJ, Geimonen E \& Andersen J 2000 Increased expression of estrogen receptor $\beta$ in human uterine smooth muscle at term. European Journal of Endocrinology 142 92-99. (doi:10.1530/eje.0.1420092)

Wu WX, Ma XH, Coksaygan T, Chakrabarty K, Collins V, Rose J \& Nathanielsz PW 2004 Prostaglandin mediates premature delivery in pregnant sheep induced by estradiol at 121 days of gestational age. Endocrinology 145 1444-1452. (doi:10.1210/en.2003-1142)

Yoon S \& Seger R 2006 The extracellular signal-regulated kinase: multiple substrates regulate diverse cellular functions. Growth Factors 24 21-44. (doi:10.1080/02699050500284218)

Received in final form 4 November 2011

Accepted 8 November 2011

Made available online as an Accepted Preprint 8 November 2011 